\title{
Exploration of an Optimal Policy for Water Resources Management Including the Introduction of Advanced Sewage Treatment Technologies in Zaozhuang City, China
}

\author{
Gengyu He ${ }^{1,2,3}$, Jingjing Yan ${ }^{1,2,3, *}$, Jinghua Sha ${ }^{1,2,3}$, Ci Song ${ }^{1,2,3}$ and Shuai Zhong ${ }^{4}$ \\ 1 School of Humanities and Economic Management, China University of Geosciences, Beijing 100083, China; \\ hegy013@hotmail.com (G.H.); shajinghua@163.com (J.S.); SongCi013@outlook.com (C.S.) \\ 2 Key Laboratory of Carrying Capacity Assessment for Resource and Environment, \\ Ministry of Land and Resource, Beijing 100083, China \\ 3 Lab of Resources and Environmental Management, China University of Geosciences, Beijing 100083, China \\ 4 Institute of Geographic Sciences and Natural Resources Research, Chinese Academy of Sciences, \\ Beijing 100101, China; zhongshuai@igsnrr.ac.cn \\ * Correspondence: yanjingjing312@hotmail.com; Tel.: +86-138-1120-4763
}

Academic Editor: Giacomo Zanni

Received: 27 October 2016; Accepted: 19 December 2016; Published: 21 December 2016

\begin{abstract}
Water shortage and water pollution are important factors restricting sustainable social and economic development. As a typical coal resource-exhausted city and a node city of the South-to-North Water Transfer East Route Project in China, Zaozhuang City's water resources management faces multiple constraints such as transformation of economic development, restriction of groundwater exploitation, and improvement of water environment. In this paper, we develop a linear optimization model by input-output analysis to study water resources management with the introduction of three advanced sewage treatment technologies for pollutant treatment and reclaimed water production. The simulation results showed that from 2014 to 2020, Zaozhuang City will realize an annual GDP growth rate of $7.1 \%$ with an annual chemical oxygen demand (COD) emissions reduction rate of $5.5 \%$. The proportion of primary industry, secondary industry, and tertiary industry would be adjusted to $5.6 \%, 40.8 \%$, and $53.6 \%$, respectively. The amount of reclaimed water supply could be increased by $91 \%$ and groundwater supply could be decreased by $6 \%$. Based on the simulation, this model proposes a scientific reference on water resources management policies, including water environment control, water supply plan, and financial subsidy, to realize the sustainable development of economy and water resources usage.
\end{abstract}

Keywords: linear optimization model; water policy; industrial restructuring; water resources management; sustainable development

\section{Introduction}

With the growing population and increasing industrialization, water shortage and water pollution have become critical restricting factors against regional development where fresh water is demanded by increasing numbers of parties [1]; thus, water resources management is becoming quite a complex problem, involving economic activities, households, and the ecological system [2]. Water scarcity has become the bottleneck of sustainable development in China [3,4]. An effective water resources management program should ensure the balance of supply and demand in water allocation, improve water quality and aquatic environment, and promote economic and socially sustainable development [5]. 
Game theory and mathematical programming theory are two effective methods for water resources management research. Rogers [6] applied game theory to analyze the potential advantages of coalition in integrated water resources basin development. Safari et al. [7] compared the results of the Stackelberg game and Nash bargaining under the same environmental constraints and found that water suppliers could gain more benefits as leaders in the leader-follower model. Although game theory can reflect the behaviors of the involved parties and provide a framework for adopting a coalition strategy or subcoalition strategy when water conflicts arise [8], most of this research focused on the transboundary water management and pollutant reductions or the share of emission reductions for different players.

Mathematical programming theory provides an efficient method for optimal water allocation [9,10]. Savic et al. [11] described the advantages of genetic algorithms for the problem of least-cost design of water distribution networks. Li et al. [12] developed an interval-parameter multi-stage stochastic linear programming method for water resources management under uncertainty. The mathematical programming model is suitable for conducting research on a multi-objective optimal water allocation and for water environmental management within a single administrative region $[13,14]$.

The maximization of economic benefits, social benefits, and ecological benefits are common objective functions when scholars build multi-objective models for the planning and management of water resources. Lotze-Campen et al. [15] presented a mathematical programming model that contained regional economic conditions and water constraints to study agricultural production and its environmental impacts. Liu et al. [16] developed factorial multi-stage stochastic programming with a chance-constraints approach to analyze the relationship between economic objectives and water resources management system risk. Davijani et al. [17] presented a two-objective socio-economic model for optimal water allocation among industry, agriculture, and municipal sectors.

Input-output analysis has been introduced into the linear optimization model to study the sustainable development of economy and ecology [18,19]. Yan et al. [20] proposed a dynamic linear model based on input-output theory for studying biomass resources usage, environment preservation, and economic development. In another study, the input-output model was applied to a socio-economic system to analyze water recycling [21]. Yang et al. [22] developed a dynamic optimization simulation model based on the input-output approach to study optimal policy combinations for water pollution control under the constraints of economic development. The linear optimization model has proven to be suitable for solving water resources management problems.

Water environment constraints are considered in models with environmental problems becoming increasingly prominent, but most of the studies paid more attention to the amount of emission reductions than to the specific policies and technologies applied to realize the reduction targets. Feasible simulations of water resources management that consider the reality of industry conversion and the environment should be constructed to realize sustainable development.

In this study, a linear optimization model was developed to study optimal policies for water resources management under development transformation and environment improvement. This model contained three sub-models: socio-economic, water environment, and water supply-demand. Both environmental constraints and economic transformation constraints were taken into account. Three advanced sewage treatment technologies were introduced as possibilities for improving the water environment and providing more reclaimed water. We adopted a mathematical optimization software package Linear Interactive and General Optimizer (LINGO), to express and solve the optimal simulation model. 


\section{Study Area and Methods}

\subsection{Study Area}

Zaozhuang City (Figure 1), a Chinese coal resource-exhausted city, is located in the Huaihe River Basin, in Shandong province. As an intermediate node city of the South-to-North Water Transfer East Route Project, the water resources of Zaozhuang City exert a significant impact on the water quality of the project and influence the regional environment and local development transformations. Due to the over-exploitation of groundwater, which accounts for more than $60 \%$ of the total water consumption, increasingly karst collapse points of different sizes have occurred over the past three decades or so [23]. On the other hand, Zaozhuang City has always been seen as a coal resource-based city because of its abundant coal resources. In the 21st century, Zaozhuang City has experienced rapid economic development with an average GDP growth rate of $15 \%$ annually, and coal-related industries occupied more than $60 \%$ of the total industrial output value. However, coal mining has brought a series of environmental problems to the local area, such as ground-surface settlement, groundwater pollution, and air pollution, and with the depletion of coal resources, the development of the local economy is facing unprecedented difficulties [24,25]. Zaozhuang City was classified as one of the resource-exhausted cities by the National Development and Reform Commission in 2011. Maintaining the current water allocation and using strategy will cause the water deficit to reach 208 million $\mathrm{m}^{3}$ in 2020 [26], which cannot guarantee the sustainable development of the city. Therefore, both environmental constraints and economic transformation constraints should be considered when formulating policies for water resources management.

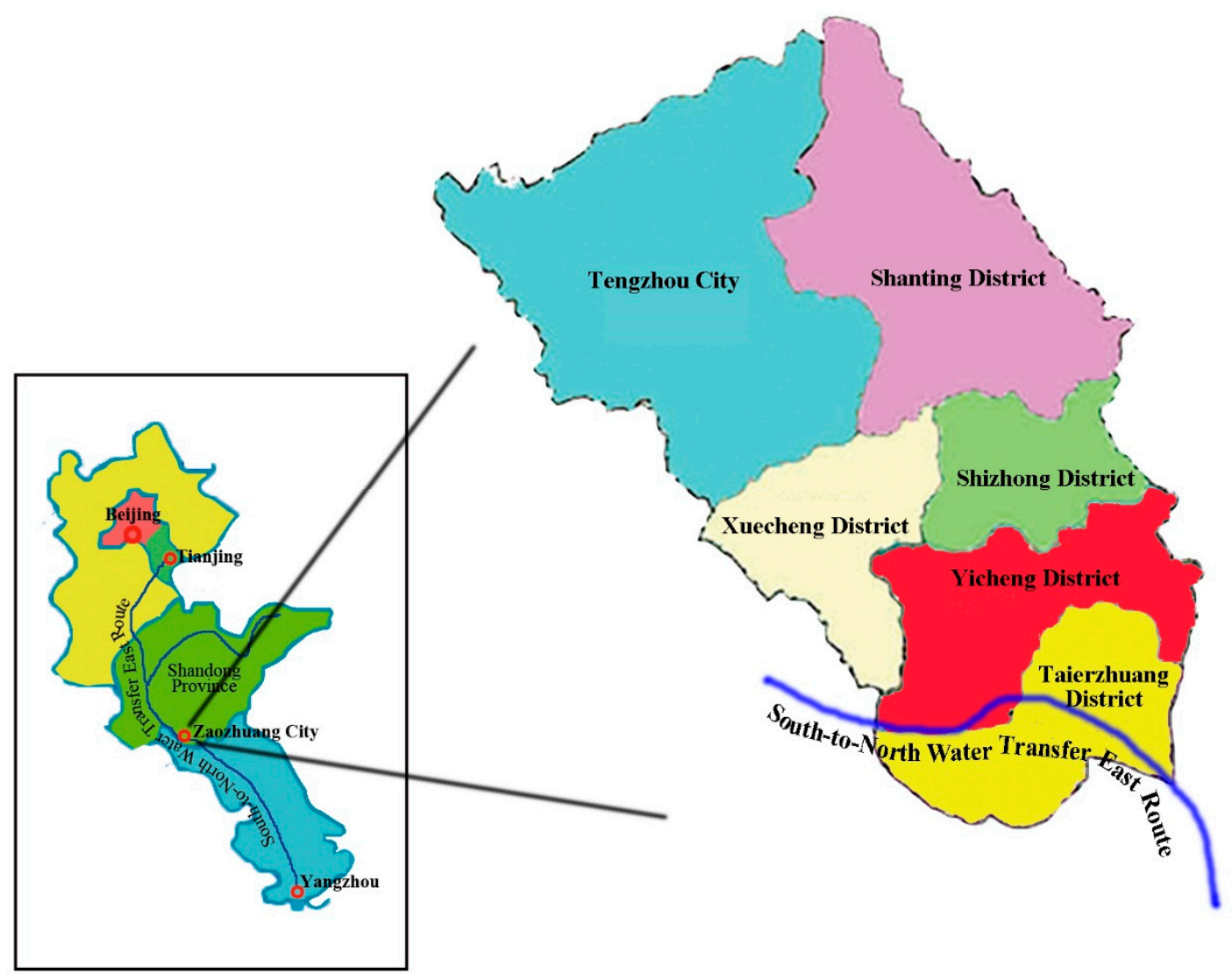

Figure 1. Location of Zaozhuang City. 


\subsection{Research Method}

The linear optimization model is based on the principles of material balance, value balance, and the input-output method. The socio-economic sub-model was developed to simulate socio-economic development and provide financial support for sewage treatment technologies. Reclaimed water production and pollutants emission reduction depended on three advanced sewage treatment technologies that were adopted in the water environment sub-model. In the water supply-demand sub-model, reclaimed water could reduce groundwater exploitation and meet the increasing water demand. The three sub-models are interrelated to simulate an optimal policy for water resources management to realize sustainable development in Zaozhuang City (Figure 2).

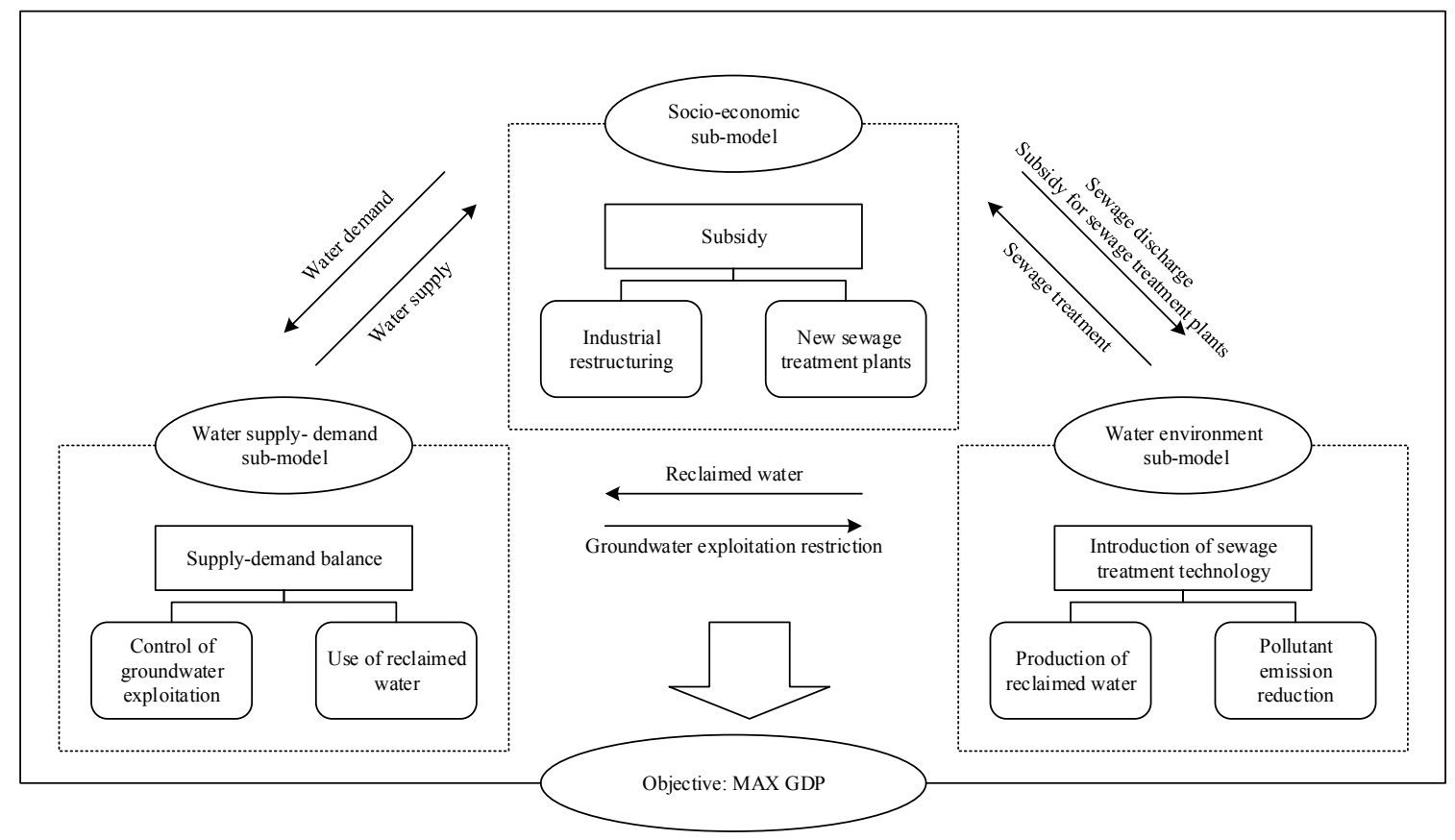

Figure 2. Model framework.

Based on the availability of resources and environmental conditions in Zaozhuang City, a synthetic policy for water resources management, including water environment control and water supply plan, could be simulated in the model framework (Table 1). First, industrial restructuring should be subject to the emission reduction targets of water pollutants and the balance of water supply and demand. Second, the increase of water supply and control of groundwater exploitation depend on the reclaimed water production by sewage treatment plants, considering the construction and operation cost and water pollutant removal rate of different technologies. The realization of these policies depends on the financial subsidies that the local government provides for economic transformation and water environment protection.

Table 1. Synthetic policy.

\begin{tabular}{cc}
\hline Policy & Measures \\
\hline Water environment control & Industrial restructuring \\
Water supply plan & Water pollutant emission reduction \\
& Sewage treatment technology selection \\
Groundwater exploitation restriction
\end{tabular}




\subsection{Data}

The published data are collected from the Zaozhuang City Master Plan (2010-2020) [26], Zaozhuang Statistical Yearbook 2014 [27], Zaozhuang City Environmental Quality Report 2014 [28], Zaozhuang City Planning of Resource City Transformation and Sustainable Development (2010-2020) [29], and Code for Classification of Urban Land Use and Planning Standards of Development Land [30]. The data pertaining to sewage treatment technologies are collected from the China Wastewater Treatment Plants Compilation [31] and the National Environmental Protection Standards of China [32], including Technical Guidelines on Water Pollution Control Engineering, Technical Specifications for Management of Municipal Wastewater Treatment Plant Operation, Technical Specifications of Domestic Pollution Control for Town and Village, Technical Specifications for Wastewater Treatment by Membrane Biological Process, Technical Specifications for Wastewater Treatment by Biological Contact Oxidation Process, and Technical Specifications for Membrane Separation Process in Wastewater Treatment. Based on the collected data, we calculated the population growth rate, land use change rate, input-output coefficients, financial budget growth rate, water demand coefficient, ecological water demand, sewage discharge coefficient, and chemical oxygen demand (COD) emission coefficient for simulation. The base year was 2013 and the target term was from 2014 to 2020 .

\section{Modeling and Simulation}

We divided Zaozhuang's industry into nine sectors (Table A3). The optimal model contained exogenous variables (ex) and endogenous variables (en) (Tables A1 and A2).There are five districts and one country-level city in Zaozhuang City (Table A5). The technical level is set to stay the same during each year of the target term.

\subsection{Objective Function}

As a coal resource-exhausted city, economic transformation is the main feature of Zaozhuang City. The primary task of development is to maximize economic growth under environmental and resource restrictions. Therefore, the objective function is the maximization of GDP in the target term.

$$
\begin{gathered}
\operatorname{MAX} \sum_{t} \frac{1}{(1+\rho)^{t-1}} G D P(t) \\
\operatorname{GDP}(t)=\sum_{m} \delta^{m} \cdot X^{m}(t)
\end{gathered}
$$

where $X^{m}(t)$ (en) is the production of industry $m$ at time $t ; G D P(t)(\mathrm{en})$ is determined by each industry's production and value-added rate $\delta^{m}$ (ex) (Table A3); and $\rho(\mathrm{ex})$ is the social discount rate considering the net present value of future income $[20,21]$.

\subsection{Socio-Economic Sub-Model}

The socio-economic sub-model includes the population and urban land system, market equilibrium system, and financial subsidy system. The population change, land change, industrial restructuring, and financial subsidy are simulated in this model.

\subsubsection{Population and Urban Land System}

The population is divided into urban and rural sectors based on their differences in water requirement coefficients, sewage discharge coefficients, and pollutant emission factors.

$$
\begin{aligned}
& U P_{j}(t)=\left(1+R A T E_{-} U P_{j}\right) \cdot U P_{j}(t-1) \\
& R P_{j}(t)=\left(1+R A T E_{-} R P_{j}\right) \cdot R P_{j}(t-1)
\end{aligned}
$$


where $U P_{j}(t)$ (en) and $R P_{j}(t)$ (en) are urban and rural populations in region $j$ at time $t$, respectively; Rate_UP $P_{j}(\mathrm{ex})$ and $R a t e_{-} R P_{j}(\mathrm{ex})$ are urban and rural population growth rates in region $j$, respectively (Table A5).

Urban land is also divided into four types-residential land, commercial land, industrial land, and traffic land-due to the differences in pollutant emission factors.

$$
L T_{j}^{k}(t)=\left(1+R A T E_{-} L T_{j}^{k}\right) \cdot L T_{j}^{k}(t-1)
$$

where $L T_{j}^{k}(t)(\mathrm{en})$ represents the area of land type $k$ in region $j$ at time $t ; R A T E_{-} L T_{j}^{k}(\mathrm{ex})$ is the change rate of land type $k$ in region $j$.

\subsubsection{Market Equilibrium System}

The market equilibrium system depends on an input-output matrix and value balance principles. The total production of each industry, which consists of intermediate input, consumption, investment and net import, should meet the balance between demand and supply of commodities produced. To describe the influence on production induced by the investment of three advanced technologies, the investment for construction of sewage treatment plants and its coefficient that induced production are added into the system $[19,22]$.

$$
X(t) \geq A \cdot X(t)+C(t)+I(t)+N E(t)+\alpha \cdot I^{s p}(t)
$$

where $\boldsymbol{X}(\boldsymbol{t})$ (en) is the column vector of total production at time $t ; A(\mathrm{ex})$ is the input-output coefficient matrix (nine-order); $\boldsymbol{C}(\boldsymbol{t})(\mathrm{en})$ is the column vector of total consumption at time $t ; \boldsymbol{I}(\boldsymbol{t})(\mathrm{en})$ is the column vector of total investment at time $t ; N E(t)(\mathrm{en})$ is the column vector of net exports at time $t$; $I^{s p}(t)(\mathrm{en})$ is the column vector of investment for construction of sewage treatment plants at time $t$; and $\alpha(e x)$ is the diagonal matrix (nine-order) of coefficient associated with the production induced by the construction investment.

On the other hand, industrial production is influenced by capital stock and industrial subsidies that are used to reduce industry scale. Capital stock is determined by industrial investment and depreciation rate.

$$
\begin{gathered}
X^{m}(t) \leq \beta^{m} \cdot\left(K^{m}(t)-S^{m}(t)\right) \\
K^{m}(t)=K^{m}(t-1)+I^{m}(t)-\chi^{m} \cdot K^{m}(t-1)
\end{gathered}
$$

where $\beta^{m}(\mathrm{ex})$ is the ratio of capital to output of industry $m ; K^{m}(t)(\mathrm{en})$ is capital stock of industry $m$ at time $t ; S^{m}(t)(\mathrm{en})$ is industrial subsidies of industry $m$ at time $t ; I^{m}(t)(\mathrm{en})$ is the investment of industry $m$ at time $t$; and $\chi^{m}(\mathrm{ex})$ is the depreciation rate of industry $m$.

\subsubsection{Financial Subsidy System}

Financial subsidies are provided for the adjustment of industrial scale and the construction and operation of new sewage treatment plants. It is restricted by the financial budget for economic transformation and water environment protection.

$$
F B(t) \geq I^{s p}(t)+O^{s p}(t)+S^{m}(t)
$$

where $F B(t)\left(\right.$ en) is the upper limit of the financial budget at time $t ; I^{s p}(t)$ is the investment for construction of new sewage treatment plants at time $t$; and $O^{s p}(t)(\mathrm{en})$ is the investment for operation of sewage treatment plants at time $t$.

\subsection{Water Environment Sub-Model}

In the water environment sub-model, three advanced sewage treatment technologies will be considered for adoption to produce reclaimed water and improve water environment (Table 2). 
Compared with traditional sewage treatment technologies, such as the sequencing batch reactor (SBR) activated sludge process and anaerobic-anoxic-oxic (AAO) activated sludge process, the technologies introduced in this study, including the extractive membrane bio-reactor (EMBR), membrane bio-reactor (MBR), and dynamic membrane bio-reactor (DMBR) require lower construction and operation costs and have higher COD removal rates [21]. Considering the cost and the previous experiences in sewage treatment in China, EMBR technology, MBR technology, and DMBR technology are suitable for small-scale sewage treatment plants (treatment capacity less than $20,000 \mathrm{~m}^{3} /$ day), middle-scale sewage treatment plants (treatment capacity between $20,000 \mathrm{~m}^{3} /$ day and $100,000 \mathrm{~m}^{3} /$ day), and large-scale sewage treatment plants (treatment capacity more than $100,000 \mathrm{~m}^{3} /$ day), respectively.

Table 2. Parameters of sewage treatment technologies.

\begin{tabular}{ccccccc}
\hline No. & Technologies & $\begin{array}{c}\text { Construction } \\
\text { Cost (Million } \\
\text { CNY) }\end{array}$ & $\begin{array}{c}\text { Operation } \\
\text { Cost } \\
\left(\mathbf{C N Y} / \mathbf{m}^{3}\right)\end{array}$ & $\begin{array}{c}\text { Treatment } \\
\text { Capacity (Million } \\
\mathbf{m}^{3} / \text { Year) }\end{array}$ & $\begin{array}{c}\text { Reclaimed Water } \\
\text { Production Capacity } \\
\text { (Million } \mathbf{m}^{3} / \text { Year) }\end{array}$ & $\begin{array}{c}\text { COD Removal } \\
\text { Amount (mg/L) }\end{array}$ \\
\hline A & EMBR & 30 & 1.4 & 4 & 3.8 & 560 \\
B & MBR & 60 & 1.0 & 11 & 8.5 & 330 \\
C & DMBR & 160 & 2.0 & 36.5 & 30 & 345 \\
\hline
\end{tabular}

Notes: CNY: Chinese Yuan.

In recent years, advanced technologies such as MBR have been adopted to improve existing sewage treatment plants and construct new ones in Zaozhuang City. The reclaimed water produced by these advanced technologies can be used for agricultural production, secondary industry and ecological demand according to its quality. The new sewage treatment plants introduced into the model are set to operate without a construction period during the target term. The quantities of new plants are determined by total amount of treated sewage and treatment capacity per plant with different technologies during each year of the target term.

\subsubsection{Production of Reclaimed Water}

Reclaimed water comes from treated sewage in treatment plants. Sewage is produced by households and industrial production. This paper only considers stockbreeding in the primary industry when it analyzes sewage discharge and COD emissions.

$$
S W G(t)=\sum_{j} s d^{u r b a n} \cdot U P_{j}(t)+\sum_{j} s d^{r u r a l} \cdot R P_{j}(t)+\sum_{j} \sum_{m} s d^{m} \cdot X_{j}^{m}(t)
$$

where $S W G(t)(\mathrm{en})$ is the total amount of sewage discharge at time $t$; $s d^{u r b a n}(\mathrm{ex}), s d^{\text {rural }}(\mathrm{ex})$, and $s d^{m}(\mathrm{ex})$ are sewage discharge coefficients per urban resident, per rural resident, and industry $m$ (Table A4), respectively; and $X_{j}^{m}(t)(\mathrm{en})$ is the production of industry $m$ in region $j$ at time $t$.

Actually, the amount of treated sewage is less than the amount of sewage discharge because not all of the sewage can be treated. The sewage would be treated by the existing sewage treatment plants and the new ones. The sewage treatment rate is set to exceed $80 \%$ by 2020 according to the local government target [26].

$$
\begin{gathered}
S W G(t) \geq S W T(t) \\
S W T(t)=\sum_{j} \operatorname{ESWT}_{j}(t)+\sum_{j}\left(N S W T_{j}^{A}(t)+N S W T_{j}^{B}(t)+N S W T_{j}^{C}(t)\right)
\end{gathered}
$$

where $S W T(t)(\mathrm{en})$ is the total amount of treated sewage at time $t ; E S W T_{j}(t)(\mathrm{en})$ is the existing sewage treatment capacity in region $j$ at time $t$; and $N S W T_{j}^{A}(t)(\mathrm{en}), N S W T_{j}^{B}(t)(\mathrm{en})$, and $N S W T_{j}^{C}(t)(\mathrm{en})$ are treatment capacity of new sewage treatment plants with advanced technology $\mathrm{A}, \mathrm{B}$, and $\mathrm{C}$ in region $j$ at time $t$, respectively. 
The reclaimed water would be produced by the existing sewage treatment plants and the new ones.

$$
R W(t)=\sum_{j} E R W_{j}(t)+\sum_{j}\left(\varepsilon \cdot N S W T_{j}^{A}(t)+\phi \cdot N S W T_{j}^{B}(t)+\varphi \cdot N S W T_{j}^{C}(t)\right)
$$

where $R W(t)(\mathrm{en})$ is the total amount of reclaimed water at time $t ; E R W_{j}(t)(\mathrm{en})$ is the amount of existing reclaimed water in region $j$ at time $t$; and $\varepsilon(\mathrm{ex}), \phi(\mathrm{ex})$, and $\varphi(\mathrm{ex})$ are reclaimed water production coefficients of advanced technology A, B, and C, respectively.

\subsubsection{Water Quality Control System}

In Zaozhuang City, the major water pollutant is the COD whose equal standard pollution load is $75.5 \%$ [28]. Households, industries, and nonpoint sources are the main sources of water pollution. The COD emissions are determined by urban and rural populations and their COD emission coefficients, the production and COD emission coefficients of each industry, and the area and COD emission coefficients of each land type, respectively. To complete the COD emission reduction target by 2020 [26], the minimum reduction rate is set to be $2 \%$ each year.

$$
\begin{gathered}
T P^{c o d}(t)=H W P^{c o d}(t)+I W P^{c o d}(t)+N W P^{c o d}(t)-S P^{c o d}(t) \\
H W P^{c o d}(t)=\sum_{j} e r^{u r b a n} \cdot U P_{j}(t)+\sum_{j} e r^{r u r a l} \cdot R P_{j}(t) \\
I W P^{c o d}(t)=\sum_{j} \sum_{m} e r^{m} \cdot X_{j}^{m}(t) \\
N W P^{c o d}(t)=\sum_{j} \sum_{k} e r^{k} \cdot L T_{j}^{k}(t)
\end{gathered}
$$

where $T P^{c o d}(t)(\mathrm{en})$ is the total emissions of the COD at time $t ; \operatorname{HW} P^{c o d}(t)(\mathrm{en}), \operatorname{IW} P^{c o d}(t)(\mathrm{en})$, and $N W P^{c o d}(t)(\mathrm{en})$ are the COD emissions from households, industries, and nonpoint sources at time $t$, respectively; $e^{\text {urban }}(\mathrm{ex}), \mathrm{er}^{\text {rural }}(\mathrm{ex}), \mathrm{er}^{\mathrm{m}}(\mathrm{ex})$, and $\mathrm{er}^{k}(\mathrm{ex})$ are the COD emission coefficients per urban resident, per rural resident, industry $m$ (Table A4), and per unit area of land type $k$ (Table A6), respectively; and $S P^{c o d}(t)(\mathrm{en})$ is the removal amount of the COD by sewage treatment at time $t$.

On the other hand, part of the COD is also removed during sewage treatment by the existing sewage treatment plants and the new ones.

$$
S P^{c o d}(t)=\sum_{j} E S P_{j}(t)+\sum_{j}\left(\gamma \cdot N S W T_{j}^{A}(t)+\eta \cdot N S W T_{j}^{B}(t)+\iota \cdot N S W T_{j}^{C}(t)\right)
$$

where $E S P_{j}(t)(\mathrm{en})$ is the existing COD treatment amount in region $j$ at time $t ; \gamma(\mathrm{ex}), \eta(\mathrm{ex})$, and $\iota(\mathrm{ex})$ are the COD removal rates of advanced technology $\mathrm{A}, \mathrm{B}$, and $\mathrm{C}$, respectively.

\subsection{Water Supply-Demand Sub-Model}

To achieve sustainable development, the total water supply should exceed the total water demand.

$$
W S T(t) \geq W D T(t)
$$

where $W S T(t)(\mathrm{en})$ is the total amount of water supply at time $t$, and $\operatorname{WDT}(t)(\mathrm{en})$ is the total amount of water demand at time $t$.

\subsubsection{Water Supply}

Surface water, groundwater, transfer water, and reclaimed water are the main water sources in Zaozhuang City. Surface water supply and transfer water supply are set to be unchanged. 
More reclaimed water will be used to replace groundwater and ease the tight supply of groundwater in the target term.

$$
W S T(t)=L S W(t)+G W(t)+T W(t)+R W(t)
$$

where $L S W(t)(\mathrm{en}), G W(t)(\mathrm{en}), T W(t)(\mathrm{en})$, and $R W(t)(\mathrm{en})$ are surface water supply, groundwater supply, transfer water supply, and reclaimed water supply at time $t$, respectively.

Ten water source areas provide groundwater, among which five are overdraft areas where the amount of exploitation has exceeded the limit, and others are normal areas (Table 3). The total amount of groundwater supply is the summation of exploitation from all source areas.

$$
G W(t)=\sum_{o} G W \_ \text {overdraft } t_{o}(t)+\sum_{p} G W \_ \text {normal }_{p}(t)
$$

where $G W \_o v e r d r a f t_{o}(t)\left(\right.$ en) and $G W \_n o r m a l_{p}(t)($ en) are groundwater supply from overdraft source area $o$ and normal source area $p$ at time $t$, respectively.

Table 3. Classification of groundwater source areas.

\begin{tabular}{cccc}
\hline No. & Overdraft Groundwater Source Area & No. & Normal Groundwater Source Area \\
\hline $\mathbf{1}$ & Dongwangzhuang & $\mathbf{1}$ & South Area of Jin River \\
$\mathbf{2}$ & Shili Spring & $\mathbf{2}$ & Yicheng Basin \\
$\mathbf{3}$ & Kekou & $\mathbf{3}$ & Houzhangzhuang \\
$\mathbf{4}$ & Qingliang Spring & $\mathbf{4}$ & Yangzhuang Spring \\
$\mathbf{5}$ & Tengxi Plain & $\mathbf{5}$ & South of Jin Spring \\
\hline
\end{tabular}

Groundwater supplies from overdraft source areas are set to be restricted within an interval calculated according to the exploitation limit and the base year when the exploitation must be less than the limit by 2020. However, exploitation of groundwater from each normal source area is set to be between the limit and the base year.

$$
\begin{gathered}
G W \_ \text {overdraft } \\
G_{o}(t) \geq B A_{o}-D_{o}^{\max } \cdot t \\
G W \_ \text {overdraft } t_{o}(t) \leq B A_{o}-D_{o}^{\min } \cdot t \\
G W \_ \text {normal }_{p}(t) \geq B A_{p} \\
G W \_ \text {normal }_{p}(t) \leq L A_{p}
\end{gathered}
$$

where $B A_{o}(\mathrm{ex})$ and $B A_{p}(\mathrm{ex})$ are the exploitation from overdraft source area $o$ and normal source area $p$ in the base year, respectively; $D_{o}^{\max }(\mathrm{ex})$ and $D_{o}^{\min }(\mathrm{ex})$ are the maximum and minimum decreasing amounts from the overdraft source area $o$, respectively; and $L A_{p}(\mathrm{ex})$ is the exploitation limit of the normal source area $p$.

\subsubsection{Water Demand}

Water-using sectors in Zaozhuang City are households, industries, and ecologies. Household water demand is determined by urban and rural populations, and their water requirement coefficients. Industrial water demand is determined by the production and water requirement coefficients of each industry. Ecological water demand is calculated according to the local government plan [26] (Table A7).

$$
\begin{gathered}
W D T(t)=H W D(t)+I W D(t)+E W D(t) \\
H W D(t)=\sum_{j} w r c^{u r b a n} \cdot U P_{j}(t)+\sum_{j} w r c^{r u r a l} \cdot R P_{j}(t)
\end{gathered}
$$




$$
\operatorname{IWD}(t)=\sum_{j} \sum_{m} w r c^{m} \cdot X_{j}^{m}(t)
$$

where $H W D(t)(\mathrm{en}), I W D(t)(\mathrm{en})$, and $E W D(t)(\mathrm{en})$ are household water demand, industrial water demand, and ecological water demand at time $t$, respectively; $w_{r c} c^{u r b a n}(\mathrm{ex})$, $w^{\text {rural }}{ }^{\text {rul }}(\mathrm{ex})$, and $\omega r c^{m}(\mathrm{ex})$ are water requirement coefficients per urban resident, per rural resident, and industry $m$ (Table A3), respectively.

\section{Results}

The simulation results can reflect the state of economy and the water environment under environmental constraints and economic transformation constraints in the target term and establish the synthetic policies about water environment control and water supply plan for water resources management in Zaozhuang City.

\subsection{Economic Development}

The aim of industrial restructuring is to realize industrial transformation and steady growth of the economy while improving the water environment in Zaozhuang City. The adjustment results of each industry are shown in Figure 3. The proportion of primary industry falls from $8.2 \%$ in 2013 to $5.6 \%$ in 2020 because of high water consumption. Tertiary industry expands from $35.1 \%$ to $53.6 \%$ and gradually becomes the pillar industry. The proportion of extractive industry falls from $9.7 \%$ to $6.7 \%$ because of the depletion of coal resources, whereas chemical industry and other manufacturing industries, respectively, fall from $7.3 \%$ and $18.8 \%$ to $5.3 \%$ and $12.9 \%$ due to high water consumption and high pollutant emission but low value-added rate. Other industries, such as the textile and garment industry, paper industry, non-metallic mineral products industry, and building industry, respectively, fall from $6.1 \%, 3.9 \%, 5.7 \%$, and $5.2 \%$ to $4.1 \%, 2.8 \%, 5.4 \%$, and $3.6 \%$, mainly due to the small amount of capital and high pollutant emission.

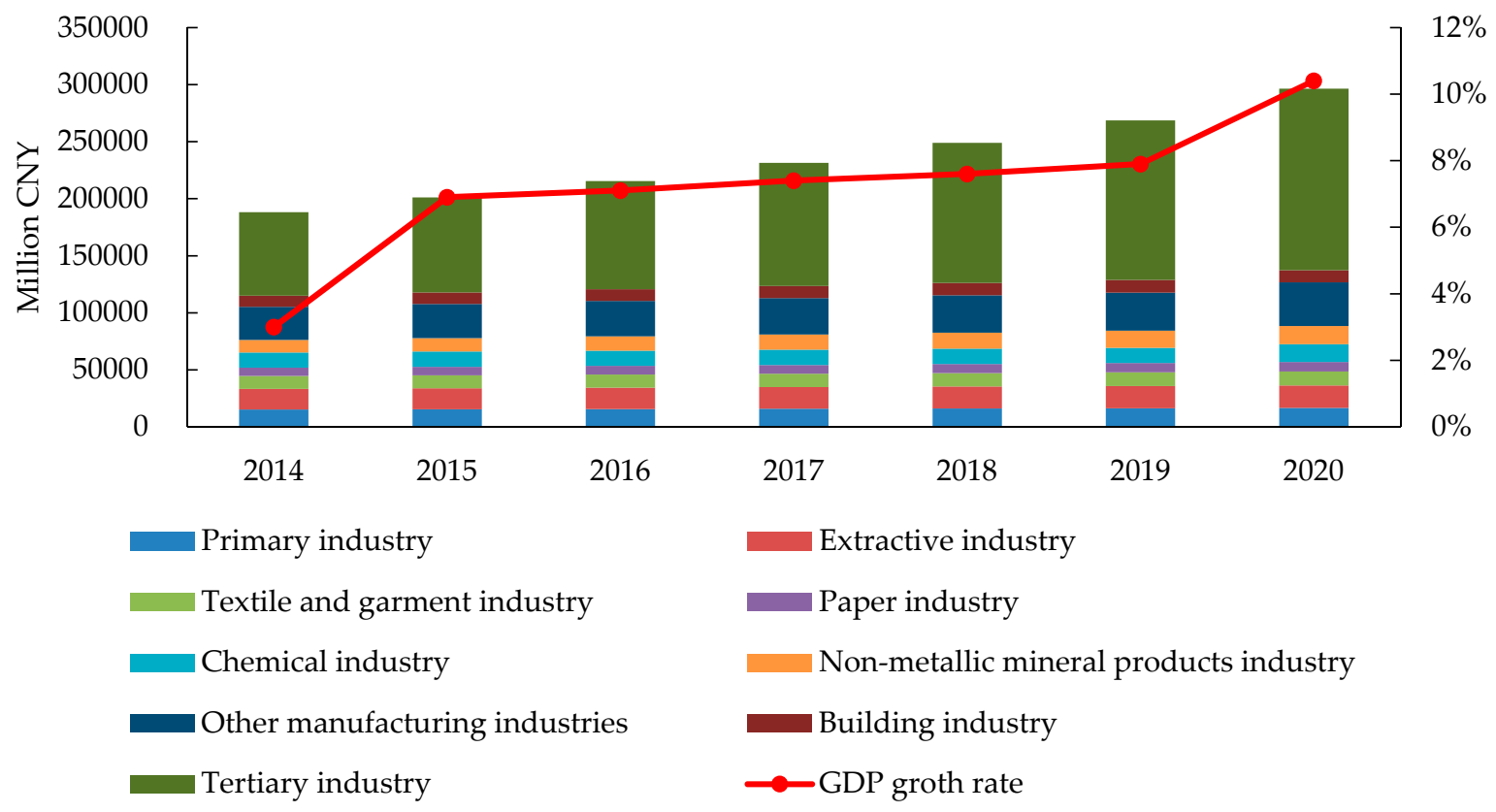

Figure 3. Simulation results of GDP and added value of each industry from 2014 to 2020.

The total financial subsidy for industrial restructuring is 1689 million CNY, including 1414 million CNY and 275 million CNY applied to adjust the scale of chemical industry and other manufacturing industries, respectively. 
During the target term, GDP in Zaozhuang City is expected to rise from 183,083 million CNY in 2013 to 296,501 million CNY in 2020, with an average growth rate of $7.1 \%$. In the first two years of the simulation, the average growth rate of GDP was $4.8 \%$ which was lower than the overall level but similar to the real value of $5.2 \%$ because secondary industry was curtailed sharply in these 2 years, but the capital of tertiary industry increased gently. Besides that, the water environment was a limiting factor because the COD emissions decreased more than they will in later years. After 2015, due to further optimization of industrial structure and more reclaimed water produced by new sewage treatment plants, the growth rate will rise steadily and finally increase to $10.4 \%$ in 2020 .

\subsection{Technology Selection}

As shown in Table 4, 16 new sewage treatment plants, among which six are technology A and ten are technology B, should be built during the target term. The construction schedule is shown in Table 5. The total financial subsidy for sewage treatment is 1272 million CNY, including 780 million CNY for construction and 492 million CNY for operation.

Table 4. Simulation results of technology selection and installation plan.

\begin{tabular}{ccccccc}
\hline No. & $\begin{array}{c}\text { Shizhong } \\
\text { District }\end{array}$ & $\begin{array}{c}\text { Xuecheng } \\
\text { District }\end{array}$ & $\begin{array}{c}\text { Yicheng } \\
\text { District }\end{array}$ & $\begin{array}{c}\text { Taierzhuang } \\
\text { District }\end{array}$ & $\begin{array}{c}\text { Shanting } \\
\text { District }\end{array}$ & $\begin{array}{c}\text { Tengzhou } \\
\text { City }\end{array}$ \\
\hline A & 0 & 0 & 1 & 1 & 3 & 1 \\
B & 0 & 2 & 1 & 1 & 2 & 4 \\
C & 0 & 0 & 0 & 0 & 0 & 0 \\
\hline
\end{tabular}

Table 5. Simulation results of sewage treatment plant construction schedule.

\begin{tabular}{cccccccc}
\hline No. & $\mathbf{2 0 1 4}$ & $\mathbf{2 0 1 5}$ & $\mathbf{2 0 1 6}$ & $\mathbf{2 0 1 7}$ & $\mathbf{2 0 1 8}$ & $\mathbf{2 0 1 9}$ & $\mathbf{2 0 2 0}$ \\
\hline A & 2 & 1 & 1 & 0 & 0 & 2 & 0 \\
B & 0 & 1 & 1 & 2 & 2 & 1 & 3 \\
C & 0 & 0 & 0 & 0 & 0 & 0 & 0 \\
\hline
\end{tabular}

Small-scale sewage treatment plants with technology A and medium-scale sewage treatment plants with technology B are suitable for Zaozhuang City, considering population scale, industrial development and previous experiences in sewage treatment in each region. Technology $C$ is not adopted because the treatment capacity of this technology is far more than the sewage discharge amount in the target term. Shizhong District, the administrative center, already has a satisfactory sewage treatment system. However, in Yicheng District, Taierzhuang District, and Shanting District, more sewage treatment plants will be constructed to produce more reclaimed water to meet the water demand of urbanization and industrialization, because the urbanization rate is no more than $32 \%$ for each of them. Xuecheng District is the high-tech industrial zone, and the urban population has maintained a growth rate of around $2 \%$ in recent years. Xuecheng District will exert great pressure on water demand from the high-end equipment manufacturing industry, coal chemical industry, and households; thus, two plants with technology B should be built due to its higher reclaimed water production capacity. For Tengzhou City, both the population scale and economic scale account for more than $40 \%$ of the whole city, but the sewage treatment rate is lower than average. One plant with technology A and four plants with technology B are needed in Tengzhou City.

\subsection{Water Supply and Water Environment}

\subsubsection{Water Supply}

In 2013, water supply was 718 million $\mathrm{m}^{3}$, of which groundwater and reclaimed water accounted for $61.9 \%$ and $14.2 \%$, respectively. As shown in Figure 4, with the construction of new sewage treatment 
plants, water supply will increase to 796 million $\mathrm{m}^{3}$ in 2020 . The proportion of groundwater supply will decrease to $52 \%$ in 2020 , whereas reclaimed water will increase to $26.4 \%$, which means that more than 360 million $\mathrm{m}^{3}$ of new reclaimed water can be produced in total to make up for the restriction of groundwater and meet the expansion of water demand compared to 2013. Water demand will increase from 704 million $\mathrm{m}^{3}$ to 791 million $\mathrm{m}^{3}$ at the end of the target term.

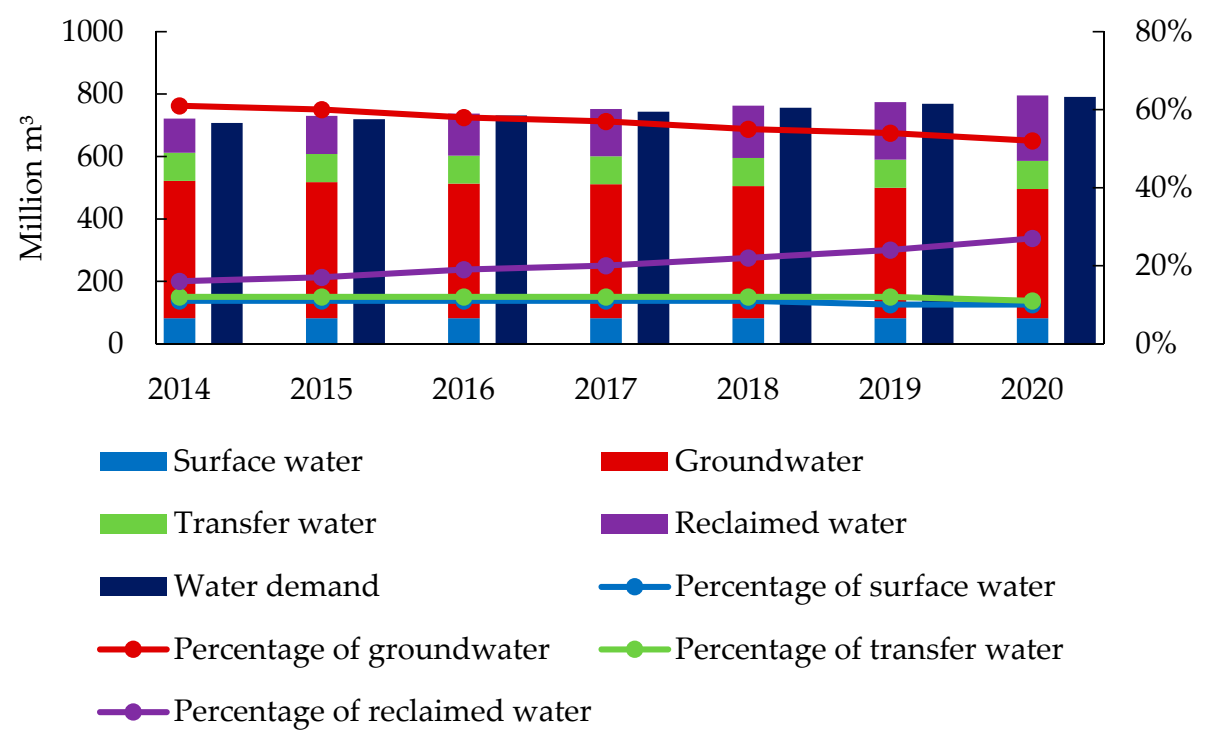

Figure 4. Simulation results of water supply structure from 2014 to 2020.

On the other hand, groundwater overdraft can be improved. Exploitation of groundwater from each overdraft source area can decrease to the limit by 2020 (Table 6). More than 120 million $\mathrm{m}^{3}$ of groundwater can be protected in total, compared to 2013.

Table 6. Simulation results of groundwater exploitation from overdraft source areas.

\begin{tabular}{cccc}
\hline & \multicolumn{2}{c}{ Exploitation Amount (Million $\mathbf{~ m}^{\mathbf{3}}$ ) } & \multirow{2}{*}{ Limit Amount (Million $\mathbf{~ m}^{\mathbf{3}}$ ) } \\
\cline { 2 - 3 } & $\mathbf{2 0 1 3}$ & $\mathbf{2 0 2 0}$ & \\
\hline Dongwangzhuang & 30 & 29.3 & 29.5 \\
Shili Spring & 18 & 16.4 & 17 \\
Kekou & 7 & 4.9 & 6.4 \\
Qingliang Spring & 21 & 18.9 & 21 \\
Tengxi Plain & 190 & 184.4 & 185.2 \\
\hline
\end{tabular}

\subsubsection{Water Environment}

The proposed changes in sewage discharge and sewage treatment from 2014 to 2020 are shown in Figure 5. The sewage treatment rate was $55.1 \%$ in 2013. However, with the construction of new sewage treatment plants, it will rise to $83.9 \%$ in 2020 , higher than the city planning target, which is $80 \%$. 


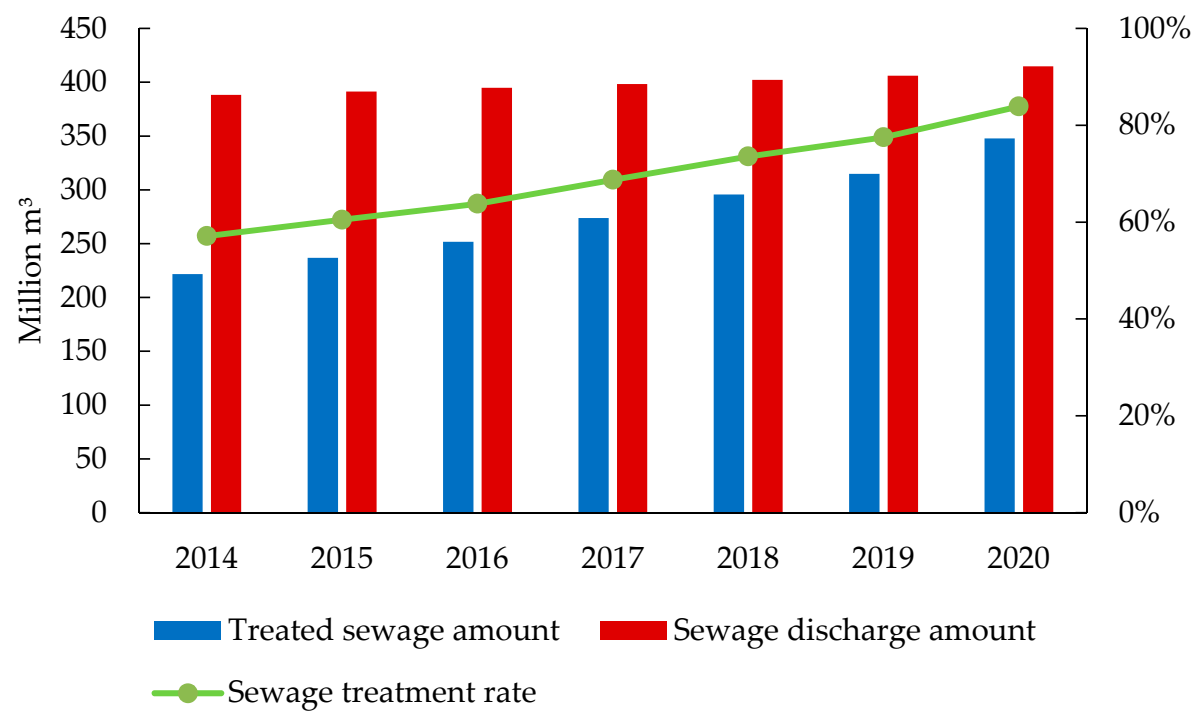

Figure 5. Simulation results of the sewage treatment situation from 2014 to 2020.

Furthermore, a high sewage treatment rate also contributes to a reduction in water pollution emissions. As shown in Figure 6, the COD emissions decrease from 71,642 tons to 48,199 tons with a decrease in emissions of $32.7 \%$, whereas the COD treatment rate increases from $61.5 \%$ to $77.3 \%$.

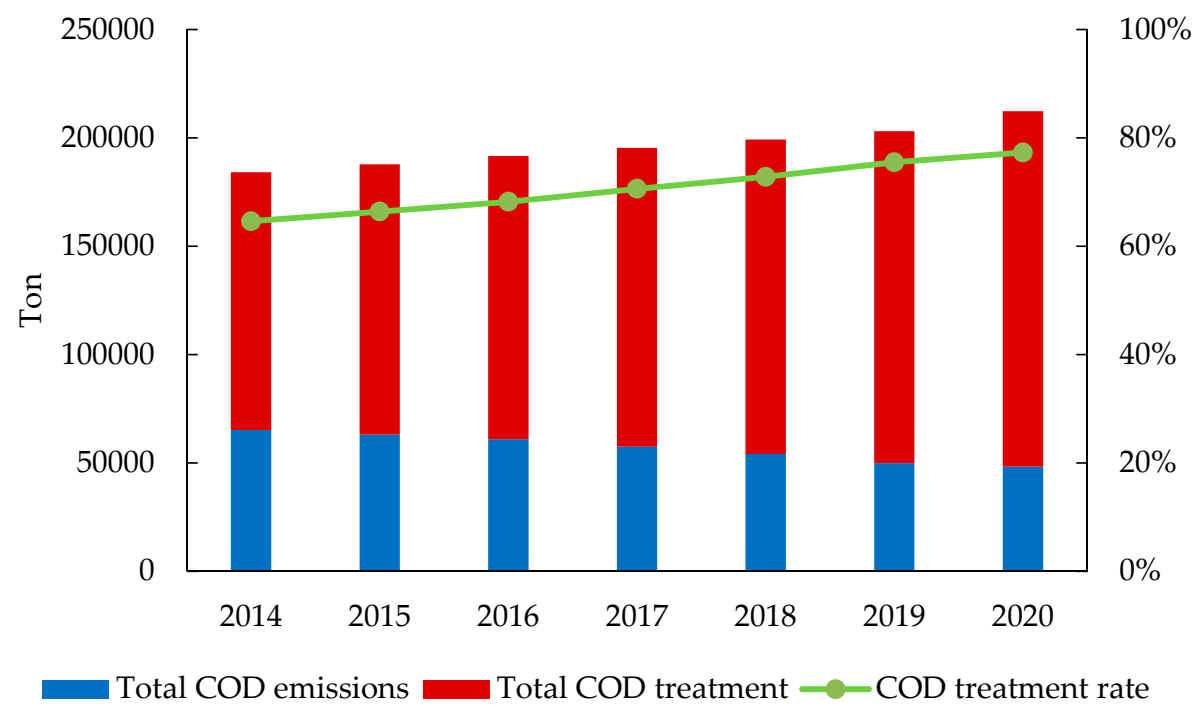

Figure 6. Simulation results of water pollutants emission from 2014 to 2020.

\section{Conclusions}

We developed a linear optimization model with the introduction of advanced sewage treatment technologies to study water resources management under development transformation and environment improvement in Zaozhuang City from 2014 to 2020. The model can provide a tool for studying water resources management policies, including water environment control, water supply plan, and financial subsidy.

A financial subsidy of 1272 million CNY, including 780 million CNY for construction and 492 million CNY for operation, is needed for the construction of 16 new sewage treatment plants with EMBR technology and MBR technology to produce reclaimed water and treat pollutants. Along with the sewage treatment plants put into use, groundwater can be replaced by reclaimed water, 
especially in the overdraft areas. The industrial structure can be optimized with a financial subsidy of 1689 million CNY to curtail industries that require high water consumption and produce high pollutant emissions. The proportion of primary industry, secondary industry, and tertiary industry can be adjusted to $5.6 \%, 40.8 \%$, and $53.6 \%$ by 2020 , respectively, and Zaozhuang City can realize an annual GDP growth rate of $7.1 \%$ with an annual COD emission reduction rate of $5.5 \%$.

During the research, we found that sewage treatment is very rare in rural areas of China. Most of the sewage treatment plants built for rural areas are just reduced-scale representations of urban implementations, ignoring the high dispersion of rural sewage discharge. In addition to sewage treatment plants, constructed wetlands and stabilization ponds are effective sewage treatment technologies suitable for regions away from water source areas. On the other hand, tax measures and price controls for environmental protection are being adopted in more and more areas of China.

To extend this study, we need to identify the characteristics of different regions and the applicable environments of different technologies to optimize the combination of technologies and study tax measures and market means in the field of water policy.

Acknowledgments: This study is supported by grants from the Fundamental Research Funds for the Central Universities (No. 2652016079), the National Natural Science Foundation of China (No. 41101559), and the Beijing Social Science Foundation (No. 14JGC116).

Author Contributions: Jingjing Yan, Jinghua Sha and Gengyu He designed the framework of the model. Gengyu He collected and calculated the data, constructed the model, and analyzed the simulation results with the help of Jingjing Yan, Ci Song and Shuai Zhong. Gengyu He wrote the paper.

Conflicts of Interest: The authors declare no conflicts of interest.

\section{Appendix}

Table A1. Superscripts and subscripts used in the model.

\begin{tabular}{ll}
\hline & \multicolumn{1}{c}{ Superscripts and Subscripts } \\
\hline$t$ & the $t$-th year of the target term, $t=1,2,3,4,5,6,7$ \\
$m$ & the $m$-th industry, $m=1,2,3,4,5,6,7,8,9$ \\
$j$ & the $j$-th region, $j=1,2,3,4,5,6$ \\
$k$ & the $k$-th land type, $k=1,2,3,4$ \\
$o$ & the $o$-th overdraft source area, $o=1,2,3,4,5$ \\
$p$ & the $p$-th normal source area, $p=1,2,3,4,5$ \\
\hline
\end{tabular}

Table A2. Definition of variables used in the model and their units.

\begin{tabular}{|c|c|c|}
\hline & Variables & Units \\
\hline sd $d^{\text {urban/rural }}$ & sewage discharge coefficient per urban/rural resident & kt $/ 10^{4}$ people \\
\hline$s d^{m}$ & sewage discharge coefficient of industry $m$ & $\mathrm{kt} /$ million $\mathrm{CNY}$ \\
\hline er urban/rural & COD emission coefficient per urban/rural resident & $\mathrm{t} / 10^{4}$ people \\
\hline$e r^{m}$ & COD emission coefficient of industry $m$ & $\mathrm{t} /$ million CNY \\
\hline$e r^{k}$ & COD emission coefficient per unit area of land type $k$ & $\mathrm{t} / \mathrm{km}^{2}$ \\
\hline wrc $^{\text {urban } / \text { rural }}$ & water requirement coefficient per urban/rural resident & kt/10 4 people \\
\hline$w r c^{m}$ & water requirement coefficient of industry $m$ & $\mathrm{kt} /$ million CNY \\
\hline$\varepsilon / \phi / \varphi$ & reclaimed water production coefficient of advanced technology A/B/C & $\%$ \\
\hline$\gamma / \eta / \iota$ & COD removal rates of advanced technology $\mathrm{A} / \mathrm{B} / \mathrm{C}$ & $\mathrm{t} /$ million $\mathrm{m}^{3}$ \\
\hline$X^{m}(t)$ & the production of industry $m$ & million CNY \\
\hline$X_{j}^{m}(t)$ & the production of industry $m$ in region $j$ & million $\mathrm{CNY}$ \\
\hline$K^{m}(t)$ & capital stock of industry $m$ & million $\mathrm{CNY}$ \\
\hline$S^{m}(t)$ & industrial subsidies of industry $m$ & million CNY \\
\hline$I^{m}(t)$ & investment of industry $m$ & million CNY \\
\hline$F B(t)$ & the upper limit of the financial budget & million CNY \\
\hline$I^{s p}(t)$ & the investment for construction of new sewage treatment plants & million CNY \\
\hline$O^{s p}(t)$ & the investment for operation of sewage treatment plants & million CNY \\
\hline
\end{tabular}


Table A2. Cont.

\begin{tabular}{|c|c|c|}
\hline \multicolumn{2}{|r|}{ Variables } & \multirow{2}{*}{$\begin{array}{r}\text { Units } \\
10^{4} \text { people }\end{array}$} \\
\hline$U P_{j}(t)$ & urban populations in region $j$ & \\
\hline$R P_{j}(t)$ & rural populations in region $j$ & $10^{4}$ people \\
\hline$L T_{j}^{k}(t)$ & the area of land type $k$ in region $j$ & $\mathrm{~km}^{2}$ \\
\hline$S W G(t)$ & the total amount of sewage discharge & million $\mathrm{m}^{3}$ \\
\hline$S W T(t)$ & the total amount of treated sewage & million $\mathrm{m}^{3}$ \\
\hline$W S T(t)$ & the total amount of water supply & million $\mathrm{m}^{3}$ \\
\hline$W D T(t)$ & the total amount of water demand & million $\mathrm{m}^{3}$ \\
\hline $\operatorname{LSW}(t)$ & surface water supply & million $\mathrm{m}^{3}$ \\
\hline$G W(t)$ & groundwater supply & million $\mathrm{m}^{3}$ \\
\hline$T W(t)$ & transfer water supply & million $\mathrm{m}^{3}$ \\
\hline$R W(t)$ & reclaimed water supply & million $\mathrm{m}^{3}$ \\
\hline$H W D(t)$ & household water demand & million $\mathrm{m}^{3}$ \\
\hline $\operatorname{IWD}(t)$ & industrial water demand & million $\mathrm{m}^{3}$ \\
\hline $\operatorname{EWD}(t)$ & ecological water demand & million $\mathrm{m}^{3}$ \\
\hline$G W \_o v e r d r a f t_{o}(t)$ & groundwater supply from overdraft source area $o$ & million $\mathrm{m}^{3}$ \\
\hline$G W \_$normal $_{p}(t)$ & groundwater supply from normal source area $p$ & million $\mathrm{m}^{3}$ \\
\hline$B A_{0}$ & exploitation from overdraft source area $o$ in base year & million $\mathrm{m}^{3}$ \\
\hline$B A_{p}$ & exploitation from normal source area $p$ in base year & million $\mathrm{m}^{3}$ \\
\hline$L A_{p}$ & the exploitation limit of normal source area $p$ & million $\mathrm{m}^{3}$ \\
\hline$D_{o}^{\max / \min }$ & $\begin{array}{l}\text { the maximum/minimum decreasing amount from overdraft source area } o \\
\text { treatment capacity of new sewage treatment plants with advanced }\end{array}$ & million $\mathrm{m}^{3}$ \\
\hline$N S W T_{j}^{A / B / C}(t)$ & technology $\mathrm{A} / \mathrm{B} / \mathrm{C}$ in region $j$ & million $\mathrm{m}^{3}$ \\
\hline $\operatorname{ESWT}_{j}(t)$ & existing sewage treatment capacity in region $j$ & million $\mathrm{m}^{3}$ \\
\hline$E R W_{j}(t)$ & the amount of existing reclaimed water in region $j$ & million $\mathrm{m}^{3}$ \\
\hline$T P^{c o d}(t)$ & the total emissions of COD & ton \\
\hline$H W P^{c o d}(t)$ & COD emissions from households & ton \\
\hline $\operatorname{IWP} P^{\operatorname{cod}}(t)$ & COD emissions from industries & ton \\
\hline$N W P^{c o d}(t)$ & COD emissions from nonpoint sources & ton \\
\hline$E S P_{j}(t)$ & the existing COD treatment amount in region $j$ & ton \\
\hline Rate_UP $P_{j}$ & urban population growth rate in region $j$ & $\%$ \\
\hline Rate_RP & rural population growth rate in region $j$ & $\%$ \\
\hline$R A T E \_L T_{j}^{k}$ & the change rate of land type $k$ in region $j$ & $\%$ \\
\hline$\delta^{m}$ & value-added rate of industry $m$ & $\%$ \\
\hline$\rho$ & the social discount rate & $\%$ \\
\hline$\beta^{m}$ & the ratio of capital to output of industry $m$ & $\%$ \\
\hline$\chi^{m}$ & the depreciation rate of industry $m$ & $\%$ \\
\hline$X(t)$ & the column vector of total production & \\
\hline$C(t)$ & the column vector of total consumption & \\
\hline$I(t)$ & the column vector of total investment & \\
\hline$N E(t)$ & the column vector of net exports & \\
\hline$I^{s p}(t)$ & the column vector of investment for construction of sewage treatment pla & \\
\hline$A$ & the input-output coefficient matrix (nine-order) & \\
\hline$\alpha$ & $\begin{array}{l}\text { the diagonal matrix (nine-order) of coefficient associated with the producti } \\
\text { construction investment }\end{array}$ & n induced by the \\
\hline
\end{tabular}

Table A3. Added values of nine industry sectors in 2013.

\begin{tabular}{lcc}
\hline \multicolumn{1}{c}{ Industry Sector } & Added Value (Million CNY) & Value-Added Rate (\%) \\
\hline Primary Industry & 149.80 & $53 \%$ \\
Extractive Industry & 178.79 & $32 \%$ \\
Textile and Garment Industry & 111.26 & $29 \%$ \\
Paper Industry & 70.97 & $31 \%$ \\
Chemical Industry & 133.81 & $25 \%$ \\
Non-Metallic Mineral Products Industry & 103.77 & $27 \%$ \\
Other Manufacturing Industries & 344.55 & $26 \%$ \\
Building Industry & 94.59 & $34 \%$ \\
Tertiary Industry & 643.27 & $53 \%$ \\
\hline
\end{tabular}


Table A4. Coefficients of nine industry sectors on water demand, sewage discharge, and COD emission.

\begin{tabular}{lccc}
\hline \multicolumn{1}{c}{ Industry Sector } & $\begin{array}{c}\text { Water Demand Coefficient } \\
\text { (kt/Million CNY) }\end{array}$ & $\begin{array}{c}\text { Sewage Discharge } \\
\text { Coefficient (kt/Million CNY) }\end{array}$ & $\begin{array}{c}\text { COD Emission Coefficient } \\
\text { (t/Million CNY) }\end{array}$ \\
\hline Primary Industry & 14.831 & - & - \\
Extractive Industry & 0.328 & 0.668 & 0.132 \\
Textile and Garment Industry & 0.259 & 0.209 & 0.302 \\
Paper Industry & 0.929 & 0.754 & 2.244 \\
Chemical Industry & 0.597 & 0.379 & 0.266 \\
Non-Metallic Mineral Products Industry & 0.161 & 0.003 & 0.002 \\
Other Manufacturing Industries & 0.292 & 0.091 & 0.217 \\
Building Industry & 0.544 & 0.264 & 0.311 \\
Tertiary Industry & 0 & 0 & 0 \\
\hline
\end{tabular}

Table A5. Average population growth rates of the target area from 2006 to 2013.

\begin{tabular}{ccc}
\hline \multirow{2}{*}{ Region } & \multicolumn{2}{c}{ Average Population Growth Rates (\%) } \\
\cline { 2 - 3 } & Urban Area & Rural Area \\
\hline Shizhong District & 0.92 & 0.93 \\
Xuecheng District & -1.23 & 2.99 \\
Yicheng District & 0.33 & 1.51 \\
Taierzhuang District & -1.02 & 1.03 \\
Shanting District & 0.79 & 0.59 \\
Tengzhou City & 4.95 & -0.54 \\
\hline
\end{tabular}

Table A6. COD emission coefficients of four urban land types $\left(\mathrm{t} / \mathrm{km}^{2}\right)$.

\begin{tabular}{cc}
\hline Land Type & COD Emission Coefficient \\
\hline Residential Land & 61.25 \\
Commercial Land & 61.25 \\
Industrial Land & 61.25 \\
Traffic Land & 36.75 \\
\hline
\end{tabular}

Table A7. Ecological water demand (million $\mathrm{m}^{3}$ ).

\begin{tabular}{lcccccccc}
\hline & $\mathbf{2 0 1 3}$ & $\mathbf{2 0 1 4}$ & $\mathbf{2 0 1 5}$ & $\mathbf{2 0 1 6}$ & $\mathbf{2 0 1 7}$ & $\mathbf{2 0 1 8}$ & $\mathbf{2 0 1 9}$ & $\mathbf{2 0 2 0}$ \\
\hline Ecological water demand & 22.74 & 23.68 & 24.67 & 25.70 & 26.77 & 27.88 & 29.04 & 30.25 \\
\hline
\end{tabular}

\section{References}

1. Nandalal, K.D.W.; Simonovic, S.P. Resolving conflicts in water sharing: A systemic approach. Water Resour. Res. 2013, 39. [CrossRef]

2. Luckman, J.; Grethe, H.; McDonald, S.; Orlov, A.; Siddig, S. An integrated economic model of multiple types and uses of water. Water Resour. Res. 2014, 50, 3875-3892. [CrossRef]

3. Davidsen, C.; Pereira-Cardenal, S.J.; Liu, S.X.; Mo, X.G.; Rosbjerg, D.; Bauer-Gottwein, P. Using stochastic dynamic programming to support water resources management in the Ziya River Basin, China. J. Water Resour. Plan. Manag. ASCE 2015, 141. [CrossRef]

4. Peng, J.; Yuan, X.M.; Qi, L.; Li, Q.L. A study of multi-objective dynamic water resources allocation modeling of Huai River. Water Sci. Technol. Water Supply 2015, 15, 817-824. [CrossRef]

5. Viaggi, D.; Zanni, G.; Raggi, M. Changing perspectives on the economics of Water. Water 2014, 6, $2969-2977$. [CrossRef]

6. Rogers, P. A game theory approach to the problems of international river basin. Water Resour. Res. 1969, 5 , 749-760. [CrossRef]

7. Safari, N.; Zarghami, M.; Szidarovszky, F. Nash bargaining and leader-follower models in water allocation: Application to the Zarrinehrud River basin, Iran. Appl. Math. Model. 2014, 38, 1959-1968. [CrossRef]

8. Madani, K. Game theory and water resources. J. Hydrol. 2010, 381, 225-238. [CrossRef] 
9. Huang, C.H.; Chang, C.T.; Ling, H.C.; Chang, C.C. A mathematical programming model for water usage and treatment network design. Ind. Eng. Chem. Res. 1999, 38, 2666-2679. [CrossRef]

10. Karterakis, S.M.; Karatzas, G.P.; Nikolos, L.K.; Papadopoulou, M.P. Application of linear programming and differential evolutionary optimization methodologies for the solution of coastal subsurface water management problems subject to environmental criteria. J. Hydrol. 2007, 342, 270-282. [CrossRef]

11. Savic, D.A.; Walters, G.A. Genetic algorithms for least-cost design of water distribution networks. J. Water Resour. Plan. Manag. ASCE 1997, 123, 67-77. [CrossRef]

12. Li, Y.P.; Huang, G.H.; Nie, S.L. An interval-parameter multi-stage stochastic programming model for water resources management under uncertainty. Adv. Water Resour. 2006, 29, 776-789. [CrossRef]

13. Abrishamchi, A.; Ebrahimian, A.; Tajrishi, M. Case study: Application of multicriteria decision making to urban water supply. J. Water Resour. Plan. Manag. ASCE 2005, 131, 326-335. [CrossRef]

14. Fattahi, P.; Fayyaz, S. A compromise programming model to integrated urban water management. Water Resour. Manag. 2010, 24, 1211-1227. [CrossRef]

15. Lotze-Campen, H.; Müller, C.; Bondeau, A.; Rost, S.; Popp, A.; Lucht, W. Global food demand, productivity growth, and the scarcity of land and water resources: A spatially explicit mathematical programming approach. Agric. Econ. 2008, 39, 325-338. [CrossRef]

16. Liu, X.M.; Huang, G.H.; Wang, S.; Fan, Y.R. Water resources management under uncertainty: Factorial multi-stage stochastic program with chance constraints. Stoch. Environ. Res. Risk Assess. 2016, 30, 945-957. [CrossRef]

17. Davijani, M.H.; Banihabib, M.E.; Anvar, A.N.; Hashemi, S.R. Multi-objective optimization model for the allocation of water resources in arid regions based on the maximization of socioeconomic efficiency. Water Resour. Manag. 2016, 30, 927-946. [CrossRef]

18. Higano, Y.; Sawada, T. The dynamic optimal policy to improve the water quality of Lake Kasumigaura. Study Reg. Sci. 1995, 26, 75-86. [CrossRef]

19. Higano, Y.; Yoneta, A. Economical policies to relieve contamination of Lake Kasumigaura. Study Reg. Sci. 1998, 29, 205-218. [CrossRef]

20. Yan, J.J.; Sha, J.H.; Chu, X.; Xu, F.; Higano, Y. Endogenous derivation of optimal environmental policies for proper treatment of stockbreeding wastes in the upstream region of the Miyun Reservoir, Beijing. Pap. Reg. Sci. 2014, 93, 477-500. [CrossRef]

21. Xiang, N.; Sha, J.H.; Yan, J.J.; Xu, F. Dynamic modeling and simulation of water environment management with a focus on a water recycling. Water 2014, 6, 17-31. [CrossRef]

22. Yang, W.; Song, J.; Higano, Y.; Tang, J. Exploration and assessment of optimal policy combination for total water pollution control with a dynamic simulation model. J. Clean. Prod. 2015, 102, 342-352. [CrossRef]

23. He, K.Q.; Wang, B.; Zhou, D.Y. Mechanism and mechanical model of karst collapse in an over-pumping area. Environ. Geol. 2004, 46, 1102-1107.

24. Wang, X.P.; Mauzerall, D.L. Evaluating impacts of air pollution in China on public health: Implication for future air pollution and energy policies. Atmos. Environ. 2006, 40, 1706-1721. [CrossRef]

25. He, K.Q.; Jia, Y.Y.; Chen, W.G.; Wang, R.L.; Luo, H.L. Evaluation of karst collapse risks induced by over-pumping and karst groundwater resource protection in Zaozhuang City, China. Environ. Earth. Sci. 2014, 71, 3443-3454. [CrossRef]

26. Zaozhuang Planning Bureau. Zaozhuang City Master Plan (2010-2020). Available online: http://www. zzsghj.gov.cn/article.asp?id=1914 (accessed on 21 November 2015).

27. Zaozhuang Statistical Bureau. Zaozhuang. Statistical Year Book 2014; China Statistics Press: Beijing, China, 2014.

28. Zaozhuang Environmental Monitoring Station. Zaozhuang City Environmental Quality Report 2014. Available online: http:/ / test.zzhb.gov.cn/index.php?m=content\&c=index\&a=show\&catid=60\&id=4926 (accessed on 21 November 2015).

29. People's Government of Zaozhuang City. Zaozhuang City Planning of Resource City Transformation and Sustainable Development (2010-2020); People's Government of Zaozhuang City: Zaozhuang, China, 2011.

30. Ministry of Housing and Urban-Rural Development of the People's Republic of China. Code for Classification of Urban. Land Use and Planning Standards of Development Land; China Architecture \& Building Press: Beijing, China, 2011. 
31. Ministry of Environmental Protection of People's Republic of China. List of National Urban Sewage Treatment Facilities. Available online: http://www.zhb.gov.cn/gkml/hbb/bgg/201404/t20140415_270550. htm (accessed on 15 November 2015).

32. Ministry of Environmental Protection of People's Republic of China. The National Environmental Protection Standards of China. Available online: http:/ /kjs.mep.gov.cn/hjbhbz/ (accessed on 15 November 2015).

(c) 2016 by the authors; licensee MDPI, Basel, Switzerland. This article is an open access article distributed under the terms and conditions of the Creative Commons Attribution (CC-BY) license (http:/ / creativecommons.org/licenses/by/4.0/). 